\title{
PENENTUAN LETAK GUDANG UNTUK MEMINIMKAN BIAYA TRANSPORTASI DENGAN PENDEKATAN CENTER OF GRAVITY
}

\section{DETERMINATION OF WAREHOUSE LOCATIONS TO MINIMIZE TRANSPORTATION COSTS IN USING CENTER OF GRAVITY APPROACH}

\author{
Muhammad Rafi Iqbal ${ }^{1^{*}}$, Ismail Hasan ${ }^{2)}$, Aldri Satria Gusmon ${ }^{3)}$ \\ 1,2,3) Jurusan Teknik Industri, Fakultas Teknik, Universitas Widyatama, Jl. Cikutra No.204A, Kota Bandung, Indonesia 40125
}

\section{ARTICLE INFORMATION}

Article history:

Received: April 29, 2020

Revised: Mei 13, 2020

Accepted: Mei 31, 2020

Keywords:

Center of Gravity

Cost Minimization

Distance

Kata kunci:

Center of Gravity

Minimasi Biaya

Jarak

\section{A B S T R A C T}

To meet the rapid demand for pharmaceutical drugs, a new warehouse is needed to distribute to various cities in West Java. This research at PT. Kimia Farma has the aim of determining the location of a new warehouse that is efficient and effective in minimizing the transportation costs of PT. Kimia Farma Plant Bandung to the location of distribution in West Java. The current conditions with warehouses in the city of Bandung prove that transportation costs at the company are very large, due to the distance from the old warehouse to the distributors. In this study, the Center of Gravity method is used to determine the location of the warehouse. The design of this research is a case study in the area of West Java with data collection methods such as interviews and using CorelDraw software to create a Cartesian diagram. The calculation results obtained using the center of gravity method for the location of the new warehouse located in Subang with coordinate points (18.36). With the new warehouse location, it can minimize transportation costs as much as Rp. 481,192 with a percentage reduction of $6.76 \%$ and the distance from the initial warehouse in Bandung to Subang and then to all distribution destinations, which is $43 \mathrm{~km}$ closer after the addition of new warehouses. and has a decreased percentage of $6.91 \%$.

\section{A B S T R A K}

Untuk memenuhi permintaan obat-obatan farmasi yang cepat, maka dibutuhkan letak gudang baru untuk mendistribusikan ke berbagai kota di Jawa Barat. Penelitian pada PT.Kimia Farma ini memiliki tujuan menentukan letak gudang baru yang efisien serta efektif dalam meminimkan biaya transportasi PT.Kimia Farma Plant Bandung ke letak distribusi di Jawa Barat. Kondisi saat ini dengan gudang di Kota Bandung membuktikan pengeluaran biaya transportasi pada perusahaan sangatlah besar, dikarenakan adanya jarak tempuh yang jauh dari gudang lama menuju para distributor. Dalam penelitian, digunakan metode center of gravity dalam mentukan letak gudang. Desain penelitian ini berupa studi kasus wilayah jawa barat dengan metode pengumpulan data berupa wawancara serta menggunakan software CorelDraw untuk membuat diagram kartesius. Hasil perhitungan yang diperoleh menggunakan metode center of gravity untuk letak gudang baru berletak di Subang dengan titik koordinat $(18,36)$. Dengan adanya letak gudang yang baru maka, dapat meminimkan biaya transportasi sebesar Rp.481.192 dengan persentase penurunan sebesar $6,76 \%$ dan jarak tempuh dari gudang awal di Bandung menuju Subang lalu menuju semua tujuan distribusinya yakni sebesar $43 \mathrm{~km}$ lebih dekat setelah adanya penambahan gudang baru dan memiliki presentase penurunan sebesar $6,91 \%$.

This is an open access article under the CC-BY license.

Name : Muhammad Rafi lqbal

Email : rafi.muhammad@widyatama.ac.id

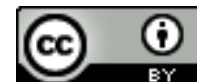




\section{PENDAHULUAN}

Kimia Farma merupakan perusahaan yang bergerak di bidang industri farmasi Indonesia. Kimia Farma pada tanggal 16 Agustus 1971 dalam bentuk hukumnya telah diubah menjadi Perseroan Terbatas, menjadi PT Kimia Farma (Persero). PT Kimia Farma (Persero) telah menjadi perusahaan yang bertahan selama lebih dari 187 tahun dan pada saat ini Kimia Farma telah berkembang menjadi salah satu perusahaan pelayanan kesehatan utama di Indonesia yang menjadi peranan sangat penting dalam pengembangan dan pembangunan bangsa dan masyarakat. [1]

Kimia Farma Trading and Distribution (KFTD) ialah anak perusahaan PT. Kimia Farma yang berdiri pada tanggal 4 Januari 2003, Kimia Farma Trading and Dsitribution (KFTD) dalam kiprahnya di industri bergerak di bidang perdagangan produk kesehatan dan kecantikan pendistribusian produk kesehatan dan kecantikan yang memiliki cabang-cabang penyebaran di berbagai kota di Indonesia. Kimia Farma Trading and Dsitribution (KFTD) Cabang Jawa Barat memiliki 4 cabang diantaranya di Bekasi, Bogor, Cirebon, dan Tasikmalaya. [1]

Pemilihan letak pusat distribusi dapat menjangkau semua pelanggan yang saat ini dilayani oleh gudang induk. Penentuan letak yang efektif dan efisien sangat penting. Letak sangat memengaruhi biaya, baik biaya tetap maupun biaya variabel. Letak memiliki pengaruh besar terhadap laba perusahaan. [2] Distribusi ialah pergerakan atau perpindahan jasa atau barang yang dimulai dari titik awal/sumber menuju ke pelanggan atau pengguna, yang melalui jaringan distribusi, serta arus pembayaran dalam kondisi yang berlawanan, hingga sampai ke penyedia atau pemosok. [3]

Didalam pemasaran suatu produk, pemasok banyak melakukan kerja sama dengan adanya perantara pemasaran (distributor) untuk mendistribusikan produknya ke pasar-pasar. Perantara pemasaran ialah suatu saluran distribusi atau saluran perdagangan. Menurut Kasmir dan Jakfar tentang saluran distribusi pemasaran ialah hubungan antara pemasok dengan pelanggan dalam hal pendistribusian baik jasa ataupun barang. [4]

Distribusi didefinisikan sebagai kegiatan pemasaran yang berusaha memperlancar serta mempermudah tersampainya jasa dan barang dari pemasok menuju pelanggan, sehingga dalam kegunaanya sesuai apa yang diperlukan. [5] Kegiatan pendistribusian ialah suatu hal yang sangat penting dalam suatu usaha manufaktur. Dalam pendistribusian, akan memperoleh sebuah sistem yang terpadu dari satu koordinat ke koordinat lain. PT. Kimia Farma mendistribusikan produknya ke berbagai cabang Kimia Farma Trading and Dsitribution (KFTD) di daerah Jawa Barat, dengan adanya gudang di Bandung membuat jarak tempuh dan biaya yang besar untuk satu kali pengiriman ke berbagai cabang Kimia Farma Trading and Dsitribution (KFTD) di Jawa Barat.

Adanya tingkat persaingan yang meninggi dalam usaha manufaktur, mendorong perusahaan ikut serta bersaing secara global dan memiliki kesiapan terhadap resiko yang akan muncul. Jaminan perusahaan yang harus dilakukan terhadap pelanggannya ialah pengiriman barang yang diminta oleh pelanggan harus sesuai serta dengan menentuan jalur/rute yang benar dengan perencanaan yang tepat, yang akan menjadikan dalam pengirimannya, barang diterima pelanggan sesuai waktu, jumlah, kondisi baik yang telah disepakati, dan tentunya dengan biaya yang rendah. Jadi dalam proses transportasi yang akan dilaksanakan tidak menimbulkan banyaknya pengeluaran biaya dan waktu. [6]

Diberbagai pengiriman barang ke banyak daerah bisa memunculkan banyaknya jalur/rute yang tidak sama serta jarak tempuh yang berbeda menimbukan jarak tempuh total yang jauh. Pada perusahaan yang sering dilihat ialah biaya transportasi dimana biaya ini pasti muncul di setiap perusahaan jasa ataupun manufaktur, serta memperlihatkan bahwa perusahaaan tersebut dapat beroperasi atau tidak beroperasi. Kenaikan atau penurunan biaya tansportasi pada perusahaan itu akan berdampak pada harga jual produk yang akan ditetapkan serta menjadikan produk tersebut dapat bersaing terhadap produk perusahaan pesaing dan memberi pengaruh di pendapatan perusahaan. [6]

Pada penelitian ini disertakan 1 jurnal internasional penelitian sebelumnya yang berhubungan dengan center of gravity. Jurnal tersebut dengan judul Finding Center of Gravity of Yoga Asana Postures to support SelfAssisted Yoga Practice, diteliti oleh K. Ponmozhi, P. Deepalakshmi, dan V. Vallinayagi pada tahun 2019 yang menceritakan tentang 
center of gravity dapat mempengaruhi pendistribusian berat tubuh secara merata untuk stabilitas. Center of Gravity akan digunakan oleh sistem bantuan untuk menginstruksikan kepada praktisi bagaimana mengubah mereka postur untuk menghindari jatuh dan memungkinkan untuk mengambil latihan yang sempurna. [7]

Penelitian yang serupa telah dilaksanakan oleh Rully dan Aldenia pada tahun 2014 dengan judul Penggunaan Metode Center of Gravity Dalam Penentuan Letak Gudang Terhadap Meminimkan Biaya Transportasi Pada PT Elangperdana Tyre Industry, pada penelitian tersebut, Rully dan Aldenia menyebutkan metode center of gravity dapat mempermudah menemukan letak gudang baru dan dapat meminimkan jarak tempuh dari gudang awal yang terletak di Bogor ke gudang baru yang terletak di Solo.

Penelitian yang serupa juga telah dilaksanakan oleh Irwanto dan Hasibuan pada tahun 2018 dengan judul Determination of Pharmaceutical Industrial Distribution Center Location Using Center of Gravity Method: Case Study At Pt Jkt, pada penelitian tersebut, Irwanto dan Hasibuan menyebutkan metode center of gravity dapat menentukan letak gudang distribusi terbaik dalam menentukan letak distribution center yang optimal pada produk farmasi.

Pada penelitian ini memilih PT. Kimia Farma sebagai objek penelitian dikarenakan kondisi saat ini dengan gudang di Kota Bandung membuktikan pengeluaran biaya transportasi pada perusahaan sangatlah besar, dikarenakan adanya jarak tempuh yang jauh dari gudang lama menuju para distributor. Pada penelitian sebelumnya telah dilaksanakan oleh Irwanto dan Hasibuan pada tahun 2018 mendapati keterbatasan hanya dengan menggunakan aplikasi google maps coordinate dalam mencari titik koordinat letak gudang dan letak para distributor, pada penelitian kali ini peneliti menggunakan aplikasi CorelDraw dalam pembuatan diagram kartesius sebagai wadah untuk menentukan titik koordinat letak gudang dan juga letak para distributor.

Tujuan dari penelitian ini ialah untuk mengetahui biaya transportasi dalam penentuan letak gudang pada PT. Kimia Farma (Persero) Tbk Unit Plant Bandung, untuk mengetahui penerapan metode center of gravity dalam meminimkan biaya transportasi pada PT. Kimia Farma (Persero) Tbk Unit Plant Bandung, dan untuk mengetahui letak gudang baru pada PT. Kimia Farma (Persero) Tbk. Unit Plant Bandung.

\section{METODE PENELITIAN}

Pada penelitian ini digunakan metode center of gravity. Desain penelitian ini berupa studi kasus wilayah Jawa Barat dengan metode pengumpulan data berupa wawancara serta menggunakan software CorelDraw untuk membuat diagram kartesius. Data biaya transportasi diambil pada tanggal 20 Maret 2020 di bagian akuntansi dan keuangan PT. Kimia Farma (Persero) Tbk Unit Plant Bandung.

Pada penelitian ini digunakan metode center of gravity. Metode Center of Gravity adalah metode yang digunakan untuk menentukan koordinat letak untuk membangun sebuah fasilitas yang akan dijadikan sebagai letak pusat distribusi. [8] Metode analisis gravitasi banyak digunakan dalam studi sosial, sumber daya ekonomi dan alam. [9] Dalam menentukan letak terbaik untuk menjadi pusat distribusi diperhitungkan letak pasar, volume barang yang di kirim ke pasar, dan biaya pengangkutan. [10]

Pada langkah awal penelitian dilakukan survey pendahuluan untuk mengetahui data yang dibutuhkan dengan melakukan pengamatan langsung maupun tidak langsung ke PT.Kimia Farma Unit Plant Bandung. Langkah kedua, dientifikasi masalah untuk mendapatkan gambaran tentang atribut yang menjadi permasalahan dan menemukan solusi dari permasalahan yang ada serta melakukan studi literatur terhadap penelitian-penelitain terdahulu sebagai dasar pernyataan kebaruan ilmiah dari artikel, dan permasalahan penelitian atau hipotesis. Langkah ketiga, penetapan tujuan yang diharapkan dari penelitian ini. Langkah keempat, menetukan metode penelitian yang akan dipakai sesuai tujuan yang akan dilaksanakan. Langkah kelima, pengumpulan data berupa letak pabrik dan letak distribusi serta demand untuk satu kali pengiriman dalam mobil truk. Langkah keenam, pengolahan data yang diolah dari pengumpulan data dengan menggunakan metode center of gravity. Langkah ketujuh, hasil dan pembahasan berisikan hasil analisa disertai dengan argumentasi yang mempunyai dasar referensi dan data-data valid tentang informasi ilmiah di dalam penelitian, terutama informasi yang relevan dengan masalah penelitian. Langkah kedelapan, Kesimpulan dicantumkan untuk 
menjawab pemasalahan yang ada dalam penelitian ini.

Berikut ialah flowchart penelitian seperti pada Gambar 1.

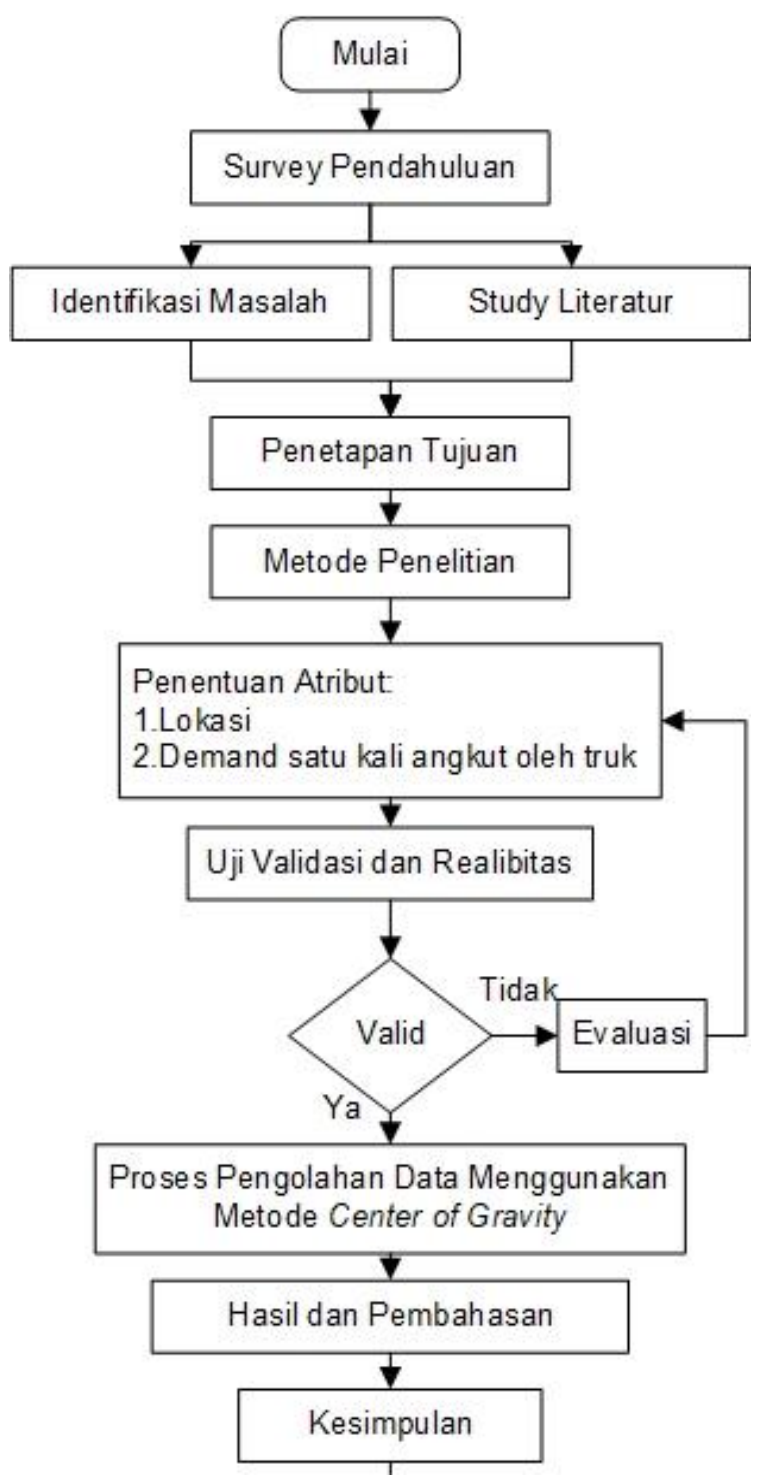

Gambar 1. Flowchart Penelitian

Dalam pendekatan center of gravity memiliki rumus sebagai berikut:

$$
\begin{gathered}
C x=\frac{\sum d i x \cdot W i}{\sum W i} \\
C y=\frac{\sum d i y \cdot W i}{\sum W i}
\end{gathered}
$$

Dimana:

$$
\begin{array}{ll}
\text { Cx } & =\text { koordinat-x dari pusat gravitasi } \\
\text { Cy } & =\text { koordinat-y dari pusat gravitasi } \\
\text { dix } & =\text { koordinat- } x \text { dari letak }-\mathrm{i} \\
\text { diy } & =\text { koordinat-y dari letak }-\mathrm{i}
\end{array}
$$

Wi = jumlah barang yang dipindahkan dari atau ke letak-i

Untuk perhitungan persentase penurunan jarak tempuh transportasi dan persentase penurunan biaya transportasi setelah mendapatkan letak gudang baru, maka digunakan perhitungan sebagai berikut :

a. Persentase penurunan jarak $=$ (Total jarak dari gudang lama menuju distributor - Total jarak dari pabrik ke gudang baru menuju distributor) / Total jarak dari gudang lama menuju distributor $x 100 \%$.

b. Persentase penurunan biaya = (Total biaya dari gudang lama menuju distributor - Total biaya dari pabrik ke gudang baru menuju distributor) / Total biaya dari gudang lama menuju distributor $\times 100 \%$.

\section{HASIL DAN PEMBAHASAN}

Kimia Farma Trading and Dsitribution (KFTD) ialah anak perusahaan PT. Kimia Farma yang berdiri pada tanggal 4 Januari 2003, Kimia Farma Trading and Dsitribution (KFTD) dalam kiprahnya di industri bergerak di bidang perdagangan produk kesehatan dan kecantikan pendistribusian produk kesehatan dan kecantikan yang memiliki cabang-cabang penyebaran di berbagai kota di Indonesia. Kimia Farma Trading and Dsitribution (KFTD) Cabang Jawa Barat memiliki 4 cabang diantaranya di Bekasi, Bogor, Cirebon, dan Tasikmalaya.

Letak pabrik bisa dijangkau dengan cepat karena terletak di tengah kota Bandung. PT. Kimia Farma Unit Plant Bandung memiliki gudang yang berletak di Bandung dan melakukan pendistribusian ke berbagai cabang

\begin{tabular}{|c|c|c|c|}
\hline No $\begin{array}{c}\text { Nama } \\
\text { Distributor }\end{array}$ & $\begin{array}{c}\text { Jarak } \\
\text { dari } \\
\text { Pabrik } \\
(\mathbf{k m})\end{array}$ & $\begin{array}{l}\text { Biaya } 1 \text { kali } \\
\text { Transportasi } \\
\text { per Truk } \\
\text { (Rp) }\end{array}$ & $\begin{array}{l}\text { Kapasitas } \\
\text { per Truk } \\
\text { (unit) }\end{array}$ \\
\hline $\begin{array}{l}\text { KFTD } \\
\text { Bekasi }\end{array}$ & 110 & 1.173 .430 & 1120 \\
\hline 2 KFTD Bogor & 185 & 1.972 .320 & 1120 \\
\hline $3 \begin{array}{l}\text { KFTD } \\
\text { Cirebon }\end{array}$ & 216 & 2.304 .000 & 1120 \\
\hline $\begin{array}{l}\text { KFTD } \\
\text { Tasikmalaya }\end{array}$ & 111 & 1.184 .000 & 1120 \\
\hline
\end{tabular}
PT. Kimia Farama Trading and Distribution di wilayah Jawa Barat. Berikut adalah jaringan distribusi PT. Kimia Farma Trading and Distribution:

Tabel 1. Jaringan Distributor KFTD 
Dari rincian pada Tabel 1, memperlihatkan, dengan adanya gudang di Bandung membuat jarak tempuh dan biaya yang besar untuk satu kali pengiriman. Maka, dilakukannya penentuan letak gudang yang efektif dan efisien diharapakan berguna untuk memperlancar proses transportasi barang yang menimbulkan jarak tempuh antara letak pendistribusian barang tidaklah terlalu jauh, sehingga jika ada jarak tempuh yang jauh antara gudang dan distributor maka akan memperbesar biaya transportasi pada perusahaan. Setelah didapatkan masing-masing koordinat pada cabang-cabang Kimia Farma Trading and Dsitribution (KFTD), lalu koordinat tersebut di masukkan ke dalam Tabel seperti pada Tabel 2.

Tabel 2. Koordinat Distributor KFTD

\begin{tabular}{cccc}
\hline \multirow{2}{*}{ No } & $\begin{array}{c}\text { Nama } \\
\text { Distributor }\end{array}$ & \multicolumn{2}{c}{ Koordinat } \\
\cline { 3 - 4 } & $\begin{array}{c}\text { Titik Ordinat } \\
\text { dix }\end{array}$ & $\begin{array}{c}\text { Titik Ordinat } \\
\text { diy }\end{array}$ \\
\hline 1 & KFTD Bekasi & -36 & 165 \\
2 & KFTD Bogor & -70 & 30 \\
& KFTD Cirebon & 95 & 15 \\
\multirow{2}{*}{4} & KFTD & & -42 \\
\\
\cline { 2 - 3 }
\end{tabular}

Setelah didapatkan titik koordinat masin-masing cabang KFTD, lalu dilakukan perhitungan koordinat $X$ dan $Y$ pada masing-masing cabang KFTD seperti pada Tabel 3.

Tabel 3. Perhitungan Koordinat $X$ dan $Y$

\begin{tabular}{|c|c|c|c|}
\hline \multirow{2}{*}{ No $\begin{array}{c}\text { Nama } \\
\text { Distributor }\end{array}$} & \multirow{2}{*}{$\begin{array}{c}\text { Ongkos } \\
\text { Angkut } \\
\text { Wi } \\
\text { (Rp/Unit) }\end{array}$} & \multicolumn{2}{|c|}{ Koordinat } \\
\hline & & $\begin{array}{c}X \\
\text { (dix.Wi) }\end{array}$ & $\begin{array}{c}Y \\
\text { (dix.Wi) }\end{array}$ \\
\hline $1 \mathrm{KFT}$ & 1.048 & -37717 & 172871 \\
\hline & 1.761 & -1 & \\
\hline $\begin{array}{l}\text { KFTD } \\
\text { Cirebo }\end{array}$ & 2.057 & 195439 & 30857 \\
\hline $4 \begin{array}{l}\text { KFTD } \\
\text { Tasikm }\end{array}$ & 1.057 & 74000 & -44400 \\
\hline & 5923 & 108441 & 212159 \\
\hline
\end{tabular}

Pada perhitungan Tabel 1, terlihat adanya biaya transportasi dikeluarkan yang sangat besar pada perusahan, disebabkan adanya jarak tempuh yang jauh dari gudang menuju semua distributor di Jawab Barat. Maka, dilakukannya penentuan letak gudang yang efektif dan efisien berguna untuk memperlancar proses transportasi barang menuju semua distributor di Jawab Barat, sehingga jarak tempuh antara letak pengiriman barang dan semua distributor di Jawab Barat tidaklah terlalu jauh, karena apabila terdapat jarak tempuh yang jauh antara gudang dan distributor maka akan memperbesar biaya transportasi pada perusahaan..

Dengan terbuktinya biaya transportasi PT. Kimia Farma (Persero) Tbk Unit Plant Bandung menuju distributor Kimia Farma Trading and Dsitribution (KFTD) di Jawa Barat yang belum minimal, maka penulis menggunakan metode center of gravity untuk menemukan letak gudang yang efektif dan efisien, berguna untuk memperlancar proses transportasi barang dari gudang ke semua distributor Kimia Farma Trading and Dsitribution (KFTD) yang ada di Jawa Barat dengan jarak tempuh serta biaya transportasi yang minimum. Pada penggunaan metode center of gravity, dapat dibuat diagram kartesius dalam peta wilayah Jawa Barat seperti pada Gambar 2. Dari hasil diagram kartesius pada Gambar 2, diperoleh koordinat dari para distributor Kimia Farma Trading and Dsitribution (KFTD) seperti pada Tabel 2. Dengan mengunakan perhitungan center of gravity, didapatkan bahwa:

$$
\begin{gathered}
C x=\frac{\sum d i x \cdot W i}{\sum W i} \\
C x=18 \\
C y=\frac{\sum d i y \cdot W i}{\sum W i} \\
C y=36
\end{gathered}
$$

Sehingga ditemukan koordinatnya ialah pada titik $(18,36)$ yang terlihat pada peta di Gambar 2, bahwa letak gudang teletak di Subang. Diprediksikan jika adanya gudang baru terletak di Subang maka akan mempermudah jalannya transportasi menuju distributor Kimia Farma Trading and Dsitribution (KFTD) yang ada di di Bogor, Bekasi, Tasikmalaya, dan Cirebon sehingga dapat meminimkan biaya transportasi yang hendak dikerluarkan PT. Kimia Farma (Persero) Tbk Unit Plant Bandung seperti ditunjukkan pada Tabel 4. Setelah dilakukan perhitungan jarak tempuh terhadap gudang yang baru, lalu dilakukan perhitungan terhadap biaya transportasi terlihat seperti Tabel 5 .

Dengan membandingkan penelitian serupa yang telah dilaksanakan oleh Rully dan Aldenia pada tahun 2014 dengan judul Penggunaan Metode Center of Gravity Dalam Penentuan Letak Gudang Terhadap Meminimkan Biaya Transportasi Pada PT Elangperdana Tyre 
Industry, pada penelitian tersebut, Rully dan Aldenia menyebutkan metode center of gravity dapat mempermudah menemukan letak gudang baru dan dapat meminimkan jarak tempuh dari gudang awal yang terletakdi Bogor ke gudang baru yang terletak di Solo, dan juga membandingkan dengan penelitian yang serupa telah dilaksanakan oleh Irwanto dan Hasibuan pada tahun 2018 dengan judul Determination of Pharmaceutical Industrial Distribution Center Location Using Center of Gravity Method: Case Study At Pt Jkt, pada penelitian tersebut,

Irwanto dan Hasibuan menyebutkan metode center of gravity dapat menentukan letak

Tabel 4. Jarak transportasi setelah adanya gudang baru gudang distribusi terbaik dalam menentukan letak distribution center yang optimal pada produk farmasi, maka dengan adanya letak gudang baru menggunakan metode center of gravity, bahwa lokasi gudang baru merupakan lokasi gudang terbaik untuk meminimkan biaya transportasi.

Pada tahapan verifikasi dengan pihak manajemen PT.Kimia Farma untuk memastikan usulan sesuai dengan strategi perusahaan. tidak sempat dilakukan oleh penulis dikarenakan keterbatasan waktu dan juga dalam mengakses data tingkat manajemen PT.Kimia Farma.

\section{No Nama Distributor}

Jarak dari-

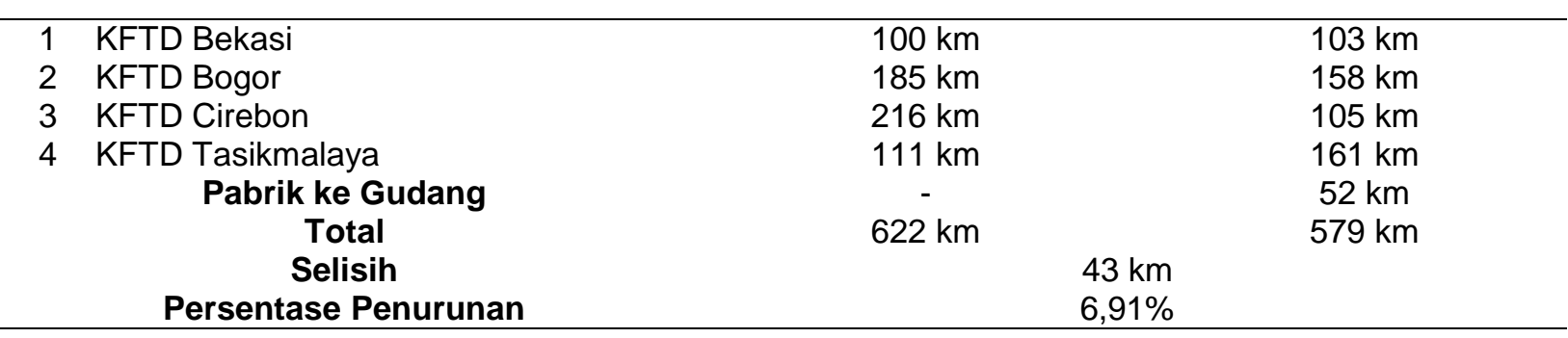

Tabel 5. Biaya transportasi setelah adanya gudang baru

\begin{tabular}{|c|c|c|c|}
\hline \multirow{2}{*}{ No } & \multirow{2}{*}{ Nama Distributor } & \multirow{2}{*}{ Gudang Lama di Bandung } & \multirow[b]{2}{*}{ Gudang Baru di Subang } \\
\hline & & & \\
\hline 1 & KFTD Bekasi & Rp. 1.173 .430 & Rp. 1.173 .430 \\
\hline 2 & KFTD Bogor & Rp. 1.972 .320 & Rp. 1.684 .468 \\
\hline 3 & KFTD Cirebon & Rp. 2.304.000 & Rp. 1.120 .000 \\
\hline 4 & KFTD Tasikmalaya & Rp. 2.304.000 & Rp. 1.717.333 \\
\hline & Pabrik ke Gudang & $r$ & Rp. 565.000 \\
\hline & Total & Rp. 6.633 .750 & Rp. 6.185 .558 \\
\hline & Selisih & \multicolumn{2}{|c|}{ Rp. 448.192} \\
\hline & Persentase Penurunan & 6,76 & \\
\hline
\end{tabular}




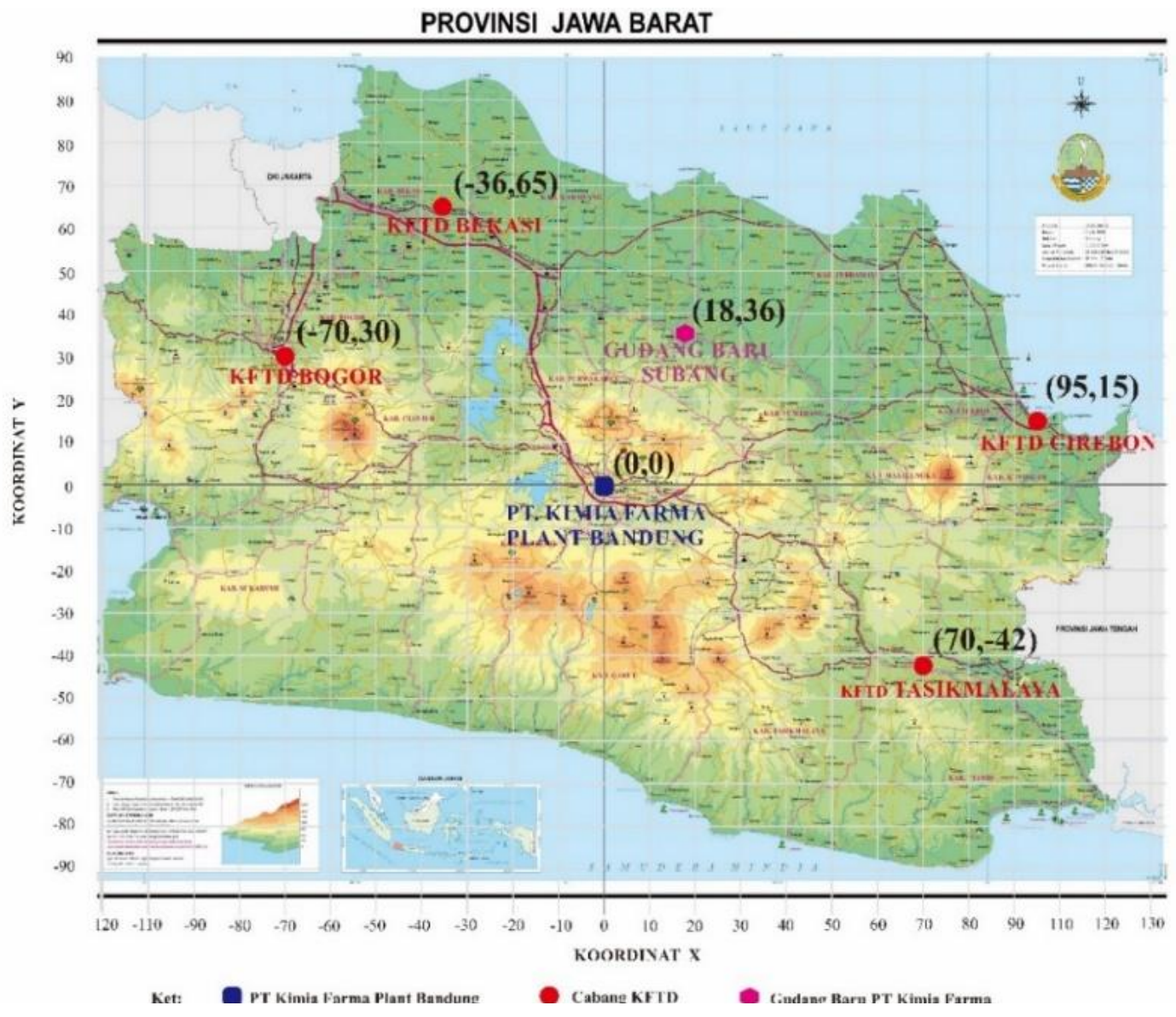

Gambar 2. Diagram kartesius letak distribusi PT. Kimia Farma (Persero) Tbk wilayah Jawa Barat

\section{KESIMPULAN}

PT. Kimia Farma Unit Plant Bandung memiliki gudang yang berletak/bertempat satu pabrik dengan pabrik PT. Kimia Farma Plant Bandung yaitu di Cicendo Kota Bandung. Letak PT. Kimia Farma Unit Plant Bandung di Kota Bandung membuktikan pengeluaran biaya transportasi yang di keluarkan sangatlah besar. Itu disebabkan karena memiliki jarak tempuh yang jauh dari gudang menuju keberbagai distributornya. Pada penelitian ini letak pasar, volume barang yang di kirim ke pasar, dan biaya pengangkutan menjadi variabel yang diperhitungkan. Setelah dilakukan penelitian terhadap metode center of gravity, didapatkan letak gudang baru yang berletak di Subang dengan koordinat $(18,36)$. Dengan adanya letak gudang baru yang berletak di Subang itu dapat mempengaruhi total biaya transportasi serta total jarak tempuh distribusi pada perusahaan. Selisih total jarak tempuh setelah adanya gudang baru di Subang adalah $43 \mathrm{~km}$ lebih dekat dari gudang lama, memiliki presentase penurunan sebesar 6,91\% dengan selisih biaya transportasi sebesar Rp.481.192 lebih murah dari gudang lama, memiliki persentase penerununan sebesar $6,76 \%$. Pada penelitian ini diharapakan menjadi kontribusi bagi PT. Kimia Farma Unit Plant Bandung untuk mendapatkan letak gudang terbaik dan juga dalam penentuan letak gudang menggunakan metode center of gravity dapat berpengaruh dalam meminimkan biaya transportasi.

Pada penlitian ini peneliti terdapat kerterbatasan pada tahapan verifikasi dengan pihak manajemen PT.Kimia Farma untuk memastikan usulan sesuai dengan strategi perusahaan, diharapkan untuk penelitian selanjutnya dapat melakukan tahapan verifikasi dengan pihak manajemen perusahaan untuk memastikan usulan sesuai dengan strategi perusahaan. dan juga untuk penelitian selanjutnya diharapkan mencari apakah ada variabel lain selain letak distribusi, volume barang yang di kirim ke distributor, dan biaya transportasi yang berpengaruh dalam mencari letak gudang yang efektif dan efisien untuk meminimkan biaya 
transportasi serta apakah masih ada aplikasi lain yang lebih mudah dan akurat selain google maps coordinate untuk mencari titik koordinat dan CorelDraw sebagai aplikasi pembuat diagram kartesius untuk mencari titik koordinat.

\section{DAFTAR PUSTAKA}

[1] R. Rosman, "Kimia Farma," 2020. https://id.wikipedia.org/wiki/Kimia_Farma (accessed Mar. 20, 2020).

[2] B. Irwanto and S. Hasibuan, "Determination of Pharmaceutical Industrial Distribution Center Location Using Center of Gravity Method: Case Study At Pt Jkt," Oper. Excell. J. Appl. Ind. Eng., vol. 10, no. 3, pp. 228-239, 2018, doi: 10.22441/oe.v10.3.2018.003.

[3] Subagyo, Akuntansi Manajemen Berbasis Desain. Yogyakarta: Gadjah Mada University Press, 2018.

[4] M. Primasyastanto, EVAPRO (Evaluasi Proyek) Teori dan Aplikasi Pada Usaha Pembesaran Ikan Sidat. Malang: UB Press, 2016.

[5] M. Arif, Supply chain Management. Yogyakarta: CV. Budi Utama, 2018.

[6] T. Rully and D. C. Aldenia, "Penggunaan Metode Center of Gravity Dalam Penentuan Lokasi Gudang Terhadap Meminimkan Biaya Transportasi Pada Pt Elangperdana Tyre Industry," JIMFE (Jurnal IIm. Manaj. Fak. Ekon., vol. 6, no. 1, pp. 64-69, 2018, doi: https://doi.org/10.34203/jimfe.v6i1.494.

[7] K. Ponmozhi, P. Deepalakshmi, and V. Vallinayagi, "Finding Centre of Gravity of Yoga Asana Postures to support SelfAssisted Yoga Practice," Int. J. Recent Technol. Eng., vol. 8, no. 4S2, pp. 706711, 2019, doi: 10.35940/ijrte.d1114.1284s219.

[8] R. Riady and T. Aspiranti, "Penentuan Lokasi Alternatif Kantor dan Pabrik Pt . Sublimindo dengan menggunakan Metode Center of Gravity dan Factor Rating," Pros. Manaj., vol. 5, no. 2, pp.
869-874, 2019.

[9] F. Wang, "The Spatial Evolution Analysis of Manufacturing Industrial Gravity Centre of Guangdong Province," Am. J. Ind. Bus. Manag., vol. 08, no. 03, pp. 721-734, 2018, doi: 10.4236/ajibm.2018.83049.

[10] A. Muadzin and W. Aryadi, "Analisis Distribusi Pengereman Terhadap Center of Gravity Pada Integrated Braking System Berbasis Matlab Simulink," Anal. Distrib. Pengereman Terhadap Cent. Gravity Pada Integr. Braking Syst. Berbas. Matlab Simulink, vol. 16, no. 2, pp. 113-124, 2019, doi: 10.15294/sainteknol.v16i2.17237.

\section{Biografi Penulis}

\section{Muhammad Rafi iqbal}

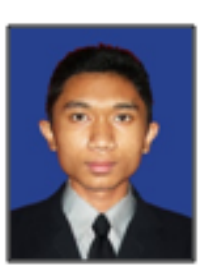

Lahir di Bandung, 14 Juni 1996. Penulis merupakan mahasiswa S1 Teknik Industri Universitas Widyatama Kota Bandung serta bekerja di salah satu perusahaan farmasi di Indonesia.

\section{Ismail Hasan}

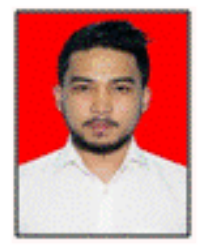

Lahir di Bandung, 19 Mei 1995. Penulis merupakan mahasiswa S1 Teknik Industri Universitas Widyatama Kota Bandung serta bekerja di salah satu perusahaan vaksin di Indonesia.

\section{Aldri Satria Gusmon}

Lahir di Sawahlunto, 17 Agustus 1998. Penulis

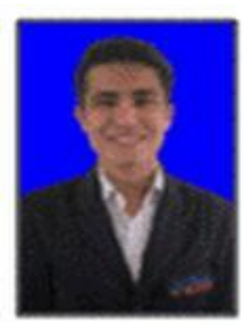
merupakan mahasiswa S1 Teknik Industri Universitas Widyatama Kota Bandung dan Asisten Laboratorium Perancangan dan Optimasi Sistem Industri Universitas Widyatama. 